\title{
АНАЛІЗ СТАНУ ВИКОНАННЯ ЗАКОНУ УКРАЇНИ «ПРО БЛАГОУСТРІЙ НАСЕЛЕНИХ ПУНКТІВ» У МІСТІ КИЄВІ
}

\section{ANALYSIS OF THE STATE OF IMPLEMENTATION OF THE LAW OF UKRAINE "ON THE IMPROVEMENT OF SETTLEMENTS" IN KYIV}

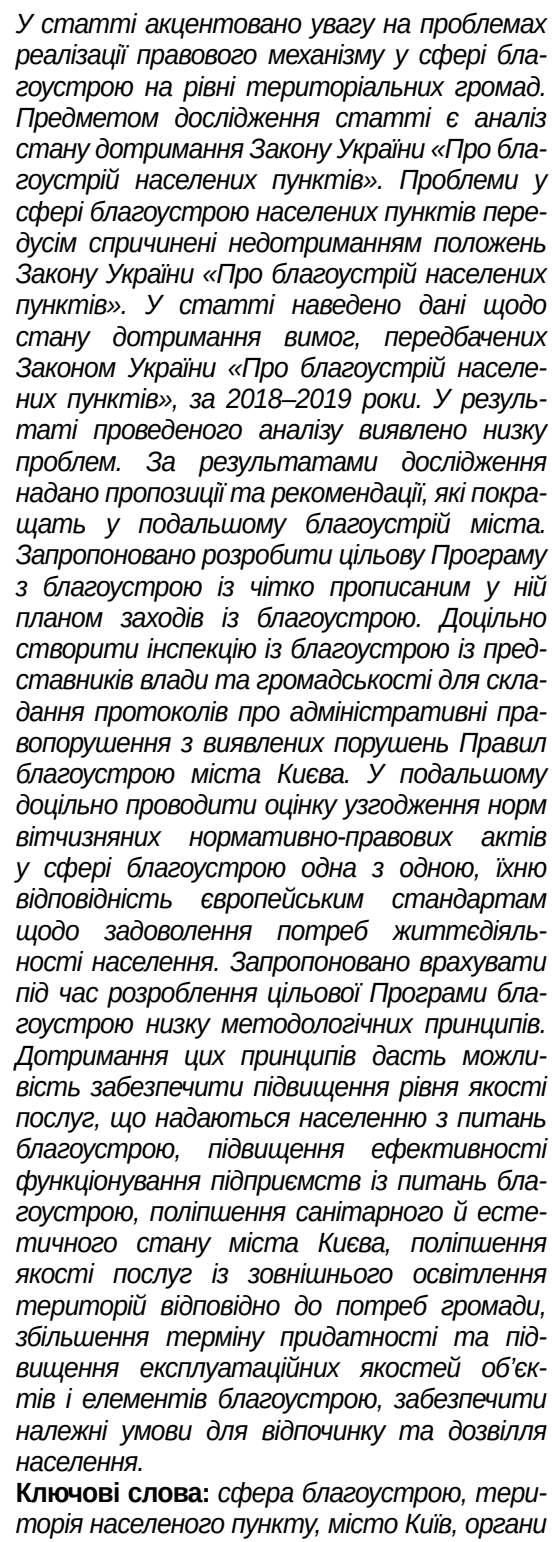
державної влади, органи місцевого самоврядування.

The article focuses on the problems of implementation of the legal mechanism in the field of landscaping at the level of territorial communities. The subject of research of the article is the analysis of the state of implementation of the Law of Ukraine "On improvement of settlements". Problems in the field of improvement of settlements are primarily caused by non-compliance with the provisions of the Law of Ukraine "On Improvement of Settlements". The article presents data on the status of implementation of the requirements of the Law of Ukraine "On Landscaping" for 2018-2019. The analysis revealed a number of problems. Based on the results of the study, suggestions and recommendations were provided that will further improve the city's landscaping. It is proposed to develop a targeted Improvement Program with a clearly defined improvement plan. It is advisable to create an improvement inspection, which would consist of representatives of the authorities and the public to draw up reports on administrative offenses from identified violations of the Rules of improvement of the city of Kyiv. In the future, it is advisable to assess the harmonization of domestic regulations in the field of landscaping, their compliance with European standards to meet the needs of the population. It is proposed to take into account a number of methodological principles during the development of the target Improvement Program. Implementation of these principles will provide an opportunity to improve the quality of services provided to the population on landscaping, improve the efficiency of enterprises on landscaping, improve the sanitary and aesthetic condition of settlements in Kyiv, improve the quality of outdoor lighting services according to community needs, increase the term suitability and improvement of operational qualities of objects and elements of improvement, to provide appropriate conditions for rest and leisure of the population.

Key words: sphere of improvement, territory of settlement, city of Kiev, public authorities, local governments.
Задорожня І.Л.

управління, місцевого самоврядування та управління містом

Національна академія державного управління при Президентові України
Постановка проблеми в загальному вигляді. Проблеми у сфері благоустрою населених пунктів (неналежне утримання об'єктів і елементів благоустрою, наявність стихійних сміттєвих звалищ, відсутність у юридичних та фізичних осіб договорів на вивезення твердих побутових відходів, невиконання робіт із відновлення благоустрою після проведення земляних та інших ремонтних робіт тощо) передусім спричинені недотриманням положень Закону України «Про благоустрій населених пунктів». У населених пунктах не забезпечено для життєдіяльності середовище, зокрема це захист довкілля, належний санітарний стан, збереження й естетичний вигляд об'єктів та елементів благоустрою, що негативно позначається на умовах життя громадян і діяльності суб'єктів господарювання.

Аналіз останніх досліджень і публікацій. Окремі питання нормативно-правового регулювання сфери благоустрою висвітлені у працях вітчизняних науковців, зокрема: О.П. Ігнатенка [1], І.О. Драган [2], В.І. Логвиненко [3], Н.І. Олійник [4]. Так, О.П. Ігнатенком досліджено нормативно-правову базу, яка регулює сферу благоустрою, 
згруповано нормативно-правові акти за функціональними ознаками, визначено ті, які мають лише рекомендаційний характер, оскільки не пройшли процедуру державної реєстрації [1, с. 36]. У роботах Є.В. Пряхіна та Є.M. Щербини [5; 6] акцентовано на адміністративно-правовому регулюванні й адміністративній відповідальності за порушення державних стандартів, норм і правил у сфері благоустрою населених пунктів.

Виділення не вирішених раніше частин загальної проблеми. Однак питання застосування норм Закону України «Про благоустрій населених пунктів» на рівні територіальних громад потребує проведення окремого аналітичного дослідження.

Мета статті - проведення аналізу стану дотримання Закону України «Про благоустрій населених пунктів» на прикладі міста Києва, формулювання пропозицій і рекомендацій, які покращать у подальшому сферу благоустрою столиці України.

Виклад основного матеріалу. Ухвалений у 2005 р. Закон України «Про благоустрій населених пунктів» $є$ базовим і визначає правові, організаційні, економічні, екологічні та соціальні засади благоустрою населених пунктів, спрямований на створення умов, сприятливих для життєдіяльності людини. Зазначеним законодавчим актом визначено правовий механізм управління процесом благоустрою. У Законі визначено, що «благоустрій населених пунктів - комплекс робіт з інженерного захисту, розчищення, осушення та озеленення території, а також соціально-економічних, організаційно-правових та екологічних заходів із покращення мікроклімату, санітарного очищення, зниження рівня шуму та інше, що здійснюються на території населеного пункту 3 метою її раціонального використання, належного утримання та охорони, створення умов щодо захисту і відновлення сприятливого для життєдіяльності людини довкілля» [7].

Законодавцем до об'єктів благоустрою населених пунктів віднесено території загального користування (парки, рекреаційні зони, сади, сквери та майданчики; пам'ятки культурної та історичної спадщини; майдани, площі, бульвари, проспекти; вулиці, дороги, провулки, узвози, проїзди, пішохідні та велосипедні доріжки; пляжі; кладовища; інші території загального користування); прибудинкові території; території будівель та споруд інженерного захисту територій; території підприємств, установ, організацій та закріплені за ними території на умовах договору. Також до них можуть належати інші території в межах населеного пункту. Суб'єктами у сфері бла- гоустрою населених пунктів є органи державної влади й органи місцевого самоврядування, підприємства, установи, організації, органи самоорганізації населення, громадяни [7].

Наведений далі аналіз стану виконання вимог, передбачених Законом України «Про благоустрій населених пунктів». за 2018-2019 рр. дозволив виявити низку проблем [8; 9].

Виявлено, що у 2018 р. 9584 населені пункти (34,6\%) мали затверджені програми із благоустрою, а у 2019 р. - лише 5030 населених пунктів (18,2\%). У містах цей показник становив на 2018 р. 388 міст (88,8\%), а на 2019 р. 383 міста $(87,4 \%)$. У місті Києві немає програми із благоустрою. У 2018 р. 10152 населених пунктів (36,6\%) мали затверджені плани заходів із благоустрою, а у 2019 р. - 8491 населений пункт $(30,7 \%)$. У містах цей показник становив на 2018 р. 92,4\%, а на 2019 р. - 91,8\%. У місті Києві немає плану заходів із благоустрою. Але в рішенні Київської міської ради «Про Програму економічного і соціального розвитку м. Києва на 2018-2020 рр. від 21 грудня 2017 р. № 1042/4049 зазначені заходи із благоустрою [10].

Програми розвитку та збереження зелених зон населених пунктів на 2018 р. мали 1609 населених пунктів (5,8\%), а у 2019 р. 1577 населених пунктів (5,7\%). У містах цей показник становив на 2018 р. 201 місто (46\%), а на 2019 р. - 200 міст (45,7\%). У місті Києві такої програми взагалі немає. Проте в Києві до 31 грудня 2020 р. продовжено дію норми рішення Київської міської ради «Про затвердження Програми розвитку зеленої зони м. Києва до 2010 р. та концепції формування зелених насаджень у центральній частині міста» від 19 липня 2005 р. № 806/3381 [11].

у 2018 р. Правила благоустрою затверджено у 12726 населених пунктах (46\%), а у 2019 р. - у 12395 населених пунктах (44,8\%). У містах цей показник становив у 2018 р. 394 міста $(90,2 \%)$, а у 2019 р. 374 міста (85,4\%). У 10158 населених пунктах (36,7\%) у 2018 р. були розроблені та затверджені схеми санітарної очистки, а у 2019 р. - у 10065 населених пунктах (36,3\%), зокрема в містах він становив майже 325 міст (74,4\%) та 306 міст (70\%) відповідно. Правила утримання домашніх тварин у 2018 р. були у 3844 населених пунктах (14\%), у 2019 р. - у 3803 населених пунктах (14\%). У 2018 р. правила затверджені у 253 містах (57,9\%), а у 2019 р. - у 246 містах (56,2\%). У місті Києві $€$ чинне рішення Київської міської ради «Про Правила благоустрою міста Києва» від 25 грудня 2008 р. № 1051/1051 [12]. 
За даними Міністерства регіонального розвитку, будівництва та житлово-комунального господарства України у 2018 р. загальна кількість об'єктів благоустрою в Україні становила понад 364,6 тис. од., із них 172,6 тис. од. у містах, у 2019 р. - понад 411,6 тис. одиниць, із них 210,3 тис. одиниць у містах. Інвентаризацію проведено у 2018 р. на 147,7 тис. (40,5\%) об'єктахблагоустрою населенихпунктів, а у 2019 р. на 291,7 тис. (70,8\%). У містах цей показник станом на 2018 р. становив 70,02 тис. (40,6\%), а на 2019 р. - 96,1 тис. (45,7\%). Загалом в Україні паспортизовано у 2018 р. 56,97 тис. (15,6\%) об'єктів благоустрою населених пунктів, у 2019 р. - 83,1 тис. (20,2\%), у містах цей показник становив у 2018 р. 29,2 тис. (17\%), а у 2019 р. - 53,9 тис. (25,6\%). Профінансовано у 2018 р. заходів із благоустрою населених пунктів на суму понад 10,88 млрд грн, зокрема на заходи із благоустрою в містах витрачено понад 5,81 млрд грн, у 2019 р. - на суму понад 25,8 млрд грн, витрачено понад 11,7 млрд грн.

Встановлено, що в Україні у 2018 р. всього 58,32 тис. (16\%) об'єктів благоустрою утримуються підприємствами, визначеними на конкурсних засадах, як це передбачено вимогами Закону України «Про благоустрій населених пунктів», а у 2019 р. - 60,9 тис. (15\%). Варто зазначити, що в місті Києві зовсім відсутні об'єкти благоустрою, які утримуються підприємствами, визначеними на конкурсних засадах. Об'єкти благоустрою утримуються комунальними підприємствами згідно з їхніми статутами, затвердженими розпорядженнями виконавчого органу Київської міської ради (Київська міська державна адміністрація).

у 2018 р. у населених пунктах діяла 251 інспекція із благоустрою, у 2019 р. 225 інспекцій. у 2018 р. у місті Києві та Волинській області ці інспекції взагалі не створені, а у 2019 р. не створені комісії лише в місті Києві. Унаслідок здійснення перевірок інспекціями із благоустрою до відповідних бюджетів надійшло понад 13,5 млн грн у 2018 р. та майже 10 млн грн у 2019 р. Водночас в Україні діяли на 2018 р. майже 1,9 тис. громадських інспекторів, які здійснили майже 40,3 тис. рейдів та перевірок, а на 2019 р. діяли понад 1,97 тис. громадських інспекторів, які здійснили майже 11,2 тис. рейдів та перевірок. У результаті їхньої діяльності було складено у 2018 р. понад 5,3 тис. протоколів, а до місцевих бюджетів надійшло приблизно 1,2 млн грн, у 2019 р. - понад 2,85 тис. протоколів, до місцевих бюджетів надійшло понад 1,22 млн грн.

у 2018 р. створено 815 комісій із питань визначення суми збитків, завданих об'єктам благоустрою внаслідок порушення законодавства, стандартів, нормативів, норм, порядків і правил у сфері благоустрою населених пунктів, у 2019 р. - 825 комісій. Кошти, що надійшли до відповідних бюджетів за результатами роботи комісій, у 2018 р. становили понад 3,23 млн грн, у 2019 р. - понад 2,58 млн грн. Залучено громадськості, насамперед молоді, до здійснення заходів із благоустрою населених пунктів у 2018 р. понад 3,55 млн осіб, у 2019 р. - 2,66 млн осіб, до здійснення заходів із благоустрою територій, прилеглих до населених пунктів, - майже 788,3 тис. осіб у 2018 р. та майже 972,6 тис. осіб у 2019 р. Також в Україні у 2018 р. понад 15,23 тис. разів висвітлювалася в засобах масової інформації проведена робота із благоустрою населених пунктів, у 2019 р. - понад 18,75 тис. разів.

Законодавством на органи місцевого самоврядування й уповноважених осіб покладено вчинення дій, що пов'язані з охороною об'єктів та елементів благоустрою, які є в комунальній власності: здійснення постійного контролю за додержанням правил благоустрою та притягнення до відповідальності осіб, винних у порушені правил благоустрою.

Отже, можемо зазначити, що проблеми у сфері благоустрою населених пунктів спричинені:

- неналежним утриманням територій населених пунктів, зокрема їх санітарним очищенням, збереженням об'єктів загального користування, а також природних ландшафтів, інших природних комплексів і об'єктів;

- незадовільним станом вулично-дорожньої мережі, зокрема доріг, тротуарів і прибудинкових проїздів у населених пунктах, їх прибирання, особливо в зимовий період, а також зовнішнього освітлення територій;

- масовим знищенням зелених насаджень, зменшенням розмірів зелених зон, як-от парки, лісопарки, рекреаційні зони тощо;

- посиленням впливу урбогенного середовища на стан зелених насаджень у населених пунктах;

- екологічно небезпечним поводженням із побутовими відходами;

- низьким рівнем упровадження системи паркування транспортних засобів;

- незадовільним станом споруд інженерного захисту територій;

- неактивною участю громадян у заходах із благоустрою території населеного пункту, мікрорайону, кварталу, вулиці або прибудинкової території за місцем проживання тощо;

- неналежним станом убезпечення дорожнього руху, запобігання виникненню аварійних ситуацій, продовження робіт з утримання й 
обслуговування покриття вулично-дорожньої мережі;

- утриманням кладовищ у належному санітарному стані тощо.

Заходи із благоустрою визначаються одними із пріоритетних у сучасних тенденціях розвитку міста Києва. Тому зазначені проблемні питання можна вирішити шляхом реалізації заходів у межах відповідних цільових програм.

Висновки. У результаті проведеного аналізу стану дотримання норм Закону України «Про благоустрій населених пунктів» можна зазначити, що їх дотримання у столичному місті $€$ неповним. У Києві треба розробити цільову Програму із благоустрою із чітко прописаним у ній планом заходів із благоустрою. На наш погляд, доцільно створити інспекцію із благоустрою із представників влади та громадськості для складання протоколів про адміністративні правопорушення з виявлених порушень Правил благоустрою міста Києва. Уважаємо, що в подальшому доцільно проводити оцінку узгодження норм вітчизняних нормативно-правових актів у сфері благоустрою одна з одною, їхньої відповідності європейським стандартам щодо задоволення потреб життєдіяльності населення. На нашу думку, основними методологічними принципами цільової Програми із благоустрою мають бути: системність; соціальна спрямованість; однозначність тлумачення положень; наукова обґрунтованість; плановість; гласність і врахування громадської думки під час здійснення.

Дотримання цих принципів дасть можливість забезпечити підвищення рівня якості послуг, що надаються населенню з питань благоустрою, підвищення ефективності функціонування підприємств із питань благоустрою, поліпшення санітарного й естетичного стану міста Києва, поліпшення якості послуг із зовнішнього освітлення територій відповідно до потреб громади, збільшення терміну придатності та підвищення експлуатаційних якостей об'єктів і елементів благоустрою, забезпечити належні умови для відпочинку та дозвілля населення.

\section{ЛІТЕРАТУРА:}

1. Ігнатенко О.П. Нормативно-правове регулювання сорери благоустрою населених пунктів. Вісник
Національної академії державного управління при Президентові України. 2014. № 2. С. 36-41. URL: http://nbuv.gov.ua/UJRN/Vnadu_2014_2_8.

2. Драган І.О. Модернізація житлово-комунального господарства в Україні: теорія, методологія, практика державного управління : монографія. Донецьк : Юго-Восток, 2010. 401 с.

3. Логвиненко В.І. Механізми державного управління розвитком житлово-комунального господарства (на прикладі формування ринку теплової енергії). Держава та регіони. Серія «Державне управління». 2009. № 2. C. 105-109.

4. Олійник Н.І. Розвиток ринку житла в Україні: теорія та практика державного регулювання : монографрія. Київ : НАДУ, 2011. 288 с.

5. Пряхін Є.В. Благоустрій населених пунктів в Україні: правове регулювання : монографрія. Львів : Львів. держ. ун-т внутр. справ, 2011. 199 с.

6. Щербина Є.М. Нормативно-правове регулювання адміністративної відповідальності за порушення державних стандартів, норм і правил у сорері благоустрою населених пунктів. Науковий вісник Дніпропетровського державного університету внутрішніх справ. 2013. № 1. С. 305-312.

7. Про благоустрій населених пунктів : Закон України від 6 вересня 2005 р. № 2807-IV. Верховна Рада України : офріційний вебсайт. URL: https://zakon.rada.gov.ua/laws/show/2807-15\#Text.

8. Аналіз стану виконання вимог, передбачених Законом України «Про благоустрій населених пунктів» за 2018 р. : інсрормаційна довідка. Міністерство розвитку громад та територій України : офріційний вебсайт. URL: https://www.minregion.gov.ua/.

9. Аналіз стану виконання вимог, передбачених Законом України «Про благоустрій населених пунктів» за 2019 р. : інфрормаційна довідка. Міністерство розвитку громад та територій України : осріційний вебсайт. URL: https://www.minregion.gov.ua/.

10. Про Програму економічного і соціального розвитку м. Києва на 2018-2020 рр. : рішення Київської міської ради від 21 грудня 2017 р. № 1042/4049. LIGA:ZAKON : офріційний вебсайт. URL: https://ips.ligazakon.net/document/MR171876.

11. Про затвердження Програми розвитку зеленої зони м. Києва до 2010 р. та концепції формування зелених насаджень у центральній частині міста : рішення Київської міської ради від 19 липня 2005 р. № 806/3381. LIGA:ZAKON : офріційний вебсайт. URL: http://kmr.ligazakon.ua/SITE2//_docki2.nsf/ alldocWWW/F568AC23F047A944C22573C00053FA80 ?OpenDocument.

12. Про Правила благоустрою міста Києва : рішення Київської міської ради від 25 грудня 2008 р. № 1051/1051. LIGA:ZAKON : офріційний вебсайт. URL: https://ips.ligazakon.net/document/view/mr081108. 